\title{
Analisis Kinerja FBMC OQAM menggunakan Kode Konvolusi
}

\author{
MIFTAKHUDIN YUSUF, ANGGUN FITRIAN ISNAWATI, SOLICHAH \\ LARASATI
}

\author{
Institut Teknologi Telkom Purwokerto, Indonesia \\ Email: 17101024@ittelkom-pwt.ac.id \\ Received 5 April 2021 | Revised 1 Mei 2021 | Accepted 12 Mei 2021
}

\begin{abstract}
ABSTRAK
Sistem FBMC merupakan teknologi MCM yang dapat menyediakan laju data bit yang tinggi. Modulasi digital OQAM digunakan untuk meningkatkan bit rate. Pengkodean kanal digunakan untuk mengoreksi kesalahan yang diakibatkan noise. Penilitian ini menggunakan pengkodean kanal kode konvolusi yang digunakan pada bagian pengirim dan algortima viterbi pada bagian penerima. Simulasi dilakukan pada FBMC OQAM dengan kode konvolusi dan tanpa kode konvolusi dengan perbandingan parameter BER dan kapasitas kanal terhadap SNR. Hasil penelitian menunjukan FBMC OQAM dengan kode konvolusi lebih baik daripada FBMC OQAM tanpa kode konvolusi pada SNR tinggi. Pada FBMC OQAM untuk mencapai BER $10^{-3}$ membutuhkan SNR 17 dB sedangkan pada FBMC OQAM dengan kode konvolusi membutuhkan SNR 16 dB. Peningkatan SNR dapat meningkatkan kapasitas kanal yang dihasilkan, pada SNR 0 dB menghasilkan 0,4535 bps/Hz dan SNR $20 \mathrm{~dB}$ menghasilkan 5,858 bps/Hz.
\end{abstract}

Kata kunci: kode konvolusi, algoritma viterbi, FBMC, OQAM, BER

\begin{abstract}
The FBMC system is an MCM technology that can provide high bit data rates. OQAM digital modulation is used to increase the bit rate. Channel coding is used to correct errors caused by noise. This research uses convolutional code channel coding used on the sender and viterbi algorithms on the receiver. Simulations are carried out on FBMC OQAM with convolutional code and without convolutional code with a comparison of BER parameters and channel capacity to SNR. The results showed that FBMC OQAM with convolutional code was better than FBMC OQAM without convolutional code at high SNR. In FBMC OQAM to reach BER $10^{-3}$ requires SNR of $17 d B$ while in FBMC OQAM with convolutional code requires SNR of $16 d B$. Increasing $S N R$ can increase the resulting channel capacity, at $0 d B$ SNR it produces $0.4535 \mathrm{bps} / \mathrm{Hz}$ and SNR $20 \mathrm{~dB}$ produces $5.858 \mathrm{bps} / \mathrm{Hz}$.
\end{abstract}

Keywords: convolutional code, viterbi algorithm, FBMC, OQAM, BER 
Yusuf, dkk

\section{PENDAHULUAN}

Pada komunikasi sistem komunikasi digital pasti akan terjadi gangguan atau noise pada saluran transmisi. Noise yang timbul pada sistem komunikasi dapat mempengaruhi kualitas data yang diterima. Untuk mengurangi noise maka dibutuhkan pengkodean kanal atau channel coding yang digunakan untuk mendeteksi kesalahan dan mengoreksi kesalahan sehingga akan mendapatkan Quality of Service (QoS) yang diinginkan (Utomo, dkk, 2015). Pengkodean kanal merupakan merupakan suatu teknik untuk menekan kesalahan data yang ditransmisikan secara wireless dengan cara menambahkan bit redudansi pada data yang dikirimkan. Terdapat beberapa metode pengkodean kanal, kode konvolusi merupakan pengkodean kanal yang banyak digunakan karena kode konvolusi memiliki kinerja yang lebih baik daripada jenis pengkodean kanal block code dengan pengkodean yang sebanding (Pushpa, dkk, 2017). Hasil penelitian (Utomo, dkk, 2015) dengan menggunakan kode konvolusi lebih pada daripada tanpa kode konvolusi pada sistem OFDM, dimana untuk mencapai BER $10^{-3}$ pada kanal AWGN menggunakan kode konvolusi membutuhkan Eb/No $6 \mathrm{~dB}$, sedangkan uncoded sistem membutuhkan Eb/No $10 \mathrm{~dB}$. Penelitian (Prayoga, dkk, 2017) membahas penggunaan kode konvolusi pada sistem MCDSSS dan menunjukan hasil lebih baik menggunakan kode konvolusi daripada tanpa kode konvolusi dimana untuk mencapai BER $10^{-3}$ pada sistem coded membutuhkan Eb/No $-7 \mathrm{~dB}$ dan pada sistem uncoded sebesar $-3 \mathrm{~dB}$.

Untuk mengoptimalkan kinerja komunikasi wireless, dibutuhkan teknologi Multi Carier Modulation (MCM) atau modulasi pembawa jamak. MCM merupakan teknologi yang membagi bandwidth kanal menjadi beberapa beberapa subkanal (Isnawati \& Hendry, 2019). Salah satu jenis dari MCM yaitu Orthogonal Frequency Division Multiplexing (OFDM), OFDM membagi kanal pita sempit dengan memanfaatkan lebar pita yang tersedia, kanal pita sempit biasa disebut dengan istilah subcarrier. Masing-masing subcarier bersifat bebas satu dari yang lainnya (orthogona). Apabila seluruh subcarrier memenuhi syarat orthogonalitas, maka spektrum dapat saling tumpang tindih tanpa menimbulkan interferensi, sehingga dapat menghemat spektrumnya (Lynn \& Calvinus, 2017).

Pada OFDM terdapat kekurangan yang dimilikinya, yaitu mudah terganggu oleh distorsi linier dan kompleksitas implementasi Fast Fourier Transform (FFT) pada sisi receiver serta sensistif terhadap frekuensi offset pembawa (Hendry \& Isnawati, 2019). Oleh karena itu muncul sebuah metode baru, yaitu Filter Bank Multi Carier (FBMC), FBMC merupakan modifikasi dari sistem OFDM, pada FBMC menggunakan orthogonalitas untuk sub-channe/ tetangga saja. Sistem FBMC juga dapat menghemat bandwidth sedikit lebih kecil daripada OFDM dikarenakan pada sistem FBMC tidak menggunakan Cyclic Prefix (CP). Oleh sebab itu, FBMC direkomendasikan untuk komunikasi 5G karena dapat menghemat bandwidth dan kapasitasnya tinggi atau besar (Isnawati \& Hendry, 2019).

Penggunaan modulasi untuk komunikasi wireless biasanya menggunakan modulasi Quadrature Amplitude Modulation (QAM), penggunaan QAM dikarenakan lebih efisien dalam pemakaian bandwidth dibandingkan modulasi lainnya. Pada modulasi QAM juga terdapat kekurangnya, yaitu decision yang rumit dan bit rate yang rendah serta masih terdapat Intercarrier Interference (ICI) (Ramadiansyah, 2017). Sekarang muncul metode modulasi baru, yaitu Offset Quadrature Amplitude Modulation (OQAM) yang memiliki decision lebih baik dan bit rate yang lebih tinggi (Hendry \& Isnawati, 2019).

Tujuan penelitian ini adalah untuk mengetahui kinerja sistem FBMC OQAM dengan menggunakan kode konvolusi dan sistem FBMC OQAM tanpa kode konvolusi serta 
membandingkan kinerja dari kedua sistem tersebut. Penggunaan kode konvolusi digunakan pada sisi pengirim sedangkan untuk sisi penerima menggunakan algoritma viterbi.

\section{METODOLOGI}

\subsection{Pemodelan Sistem}

Tahap pertama penelitian ini yaitu membuat pemodelan sistem yang digunakan seperti yang dilihat pada Gambar 1 dan Gambar 2. Kedua pemodelan sistem tersebut merupakan pemodelan sistem uncoded FBMC OQAM dan pemodelan sistem coded FBMC OQAM dengan kode konvolusi. Parameter Signal to Noise Ratio (SNR), Bit Error Rate (BER) dan kapasitas kanal digunakan sebagai parameter pengujian sistem. Analisis dilakukan dengan membandingkan unjuk kerja parameter BER dan kapasitas kanal terhadap SNR pada sistem FBMC OQAM, baik sistem coded FBMC OQAM menggunakan kode konvolusi maupun uncoded FBMC OQAM.

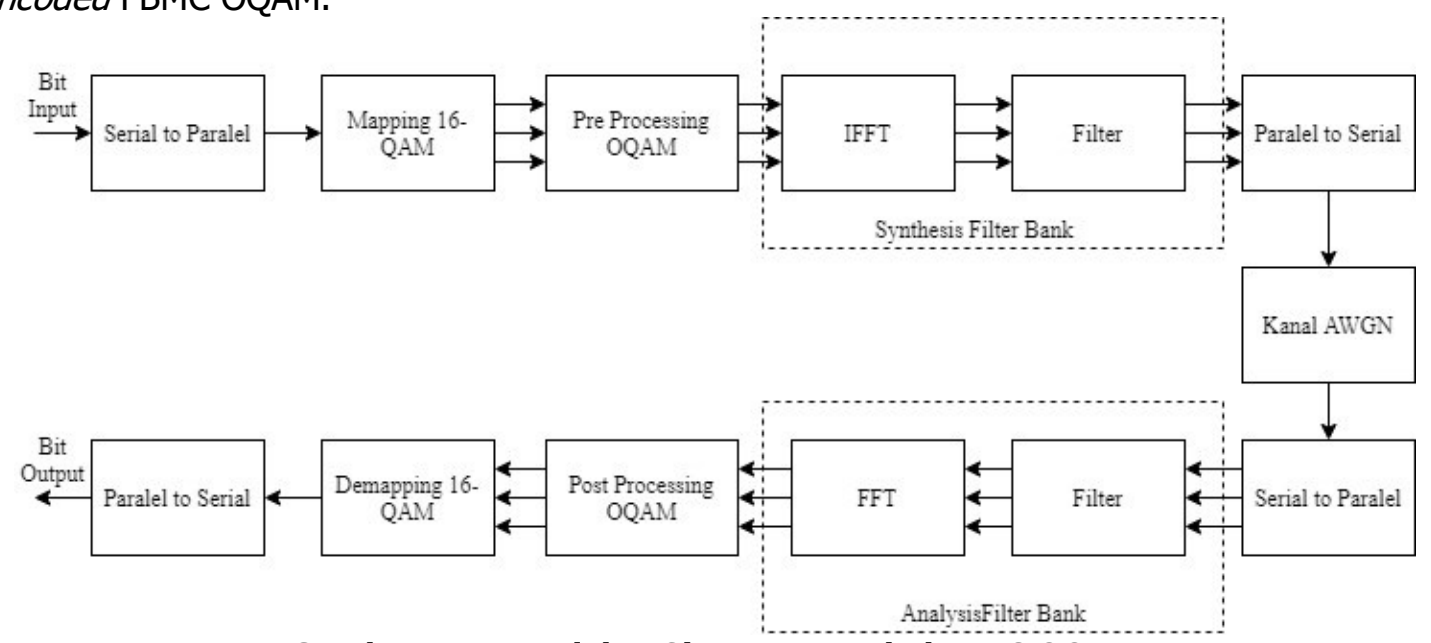

Gambar 1. Pemodelan Sistem Uncoded FBMC OQAM

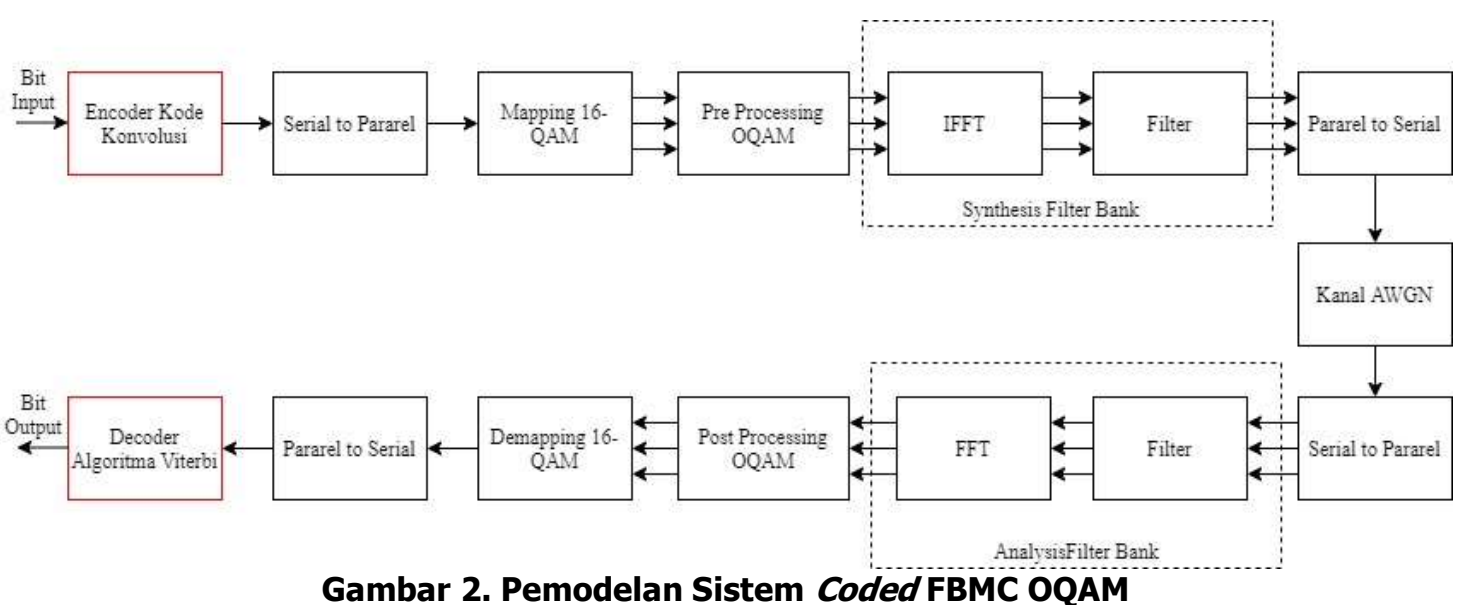

Data masukan pada penelitian ini berupa simbol acak 0 dan 1 yang merupakan simbol dari sinyal digital. Bit data yang dibangkitkan sebanyak 45000 bit dengan menggunakan perintah randn pada software Matlab. Berikut parameter simulasi untuk penelitian ini: 
Tabel 1. Parameter Simulasi

\begin{tabular}{|c|c|}
\hline Parameter & Nilai \\
\hline Bit Input & 45000 \\
\hline Code Rate Konvolusi & $1 / 2$ \\
\hline Generator Polinomial & {$[75]$} \\
\hline Algoritma Viterbi & Hard decision \\
\hline Mapping & 16 QAM \\
\hline Jumlah Antena Pengirim & 1 \\
\hline Jumlah Antena Penerima & 1 \\
\hline
\end{tabular}

\subsection{Kode Konvolusi}

Pada proses kode konvolusi, data input yang berupa bit masuk secara kontinyu akan menghasilkan beberapa bit output yang kontinyu juga. Bit output yang dihasilkan tergantung dari bit input sebelumnya (Prayoga, dkk, 2017). Maka dengan itu kode konvolusi membutuhkan memori berupa shift register. Selain shift register, komponen utama lainnya pada kode konvolusi yaitu gerbang XOR, dimana gerbang logika XOR berupa adder (Zain ,dkk, 2013).

Code rate pada kode konvolusi $k / n$ menunjukan bahwa kode konvolusi tersebut memiliki bit input $\mathrm{k}$ dengan $\mathrm{n}$ sebagai bit outputnya dengan syarat jumlah output lebih besar daripada jumlah input $(\mathrm{n}>\mathrm{k})$. Kode konvolusi didefinisikan dengan $\mathrm{C}(\mathrm{n}, \mathrm{k}, \mathrm{m})$ dengan jumlah bit input $\mathrm{k}$, jumlah bit output $\mathrm{n}$ dan memori $m$ (Elvia, dkk, 2015). Selain itu kode konvolusi didefinisikan sebagai generator polinomial, hal ini karena generator polinomial mendefinisikan aspek dari kode konvolusi yaitu panjang memori, jumlah keluaran bit (jumlah modulo-2 adder) dan koneksi antara shift register dengan gerbang logika XOR (Mahyadi \& Arifin, 2011). Berikut blok encoder kode konvolusi dengan code rate $1 / 2$ (Mamiek \& Moegiharto, 2014):

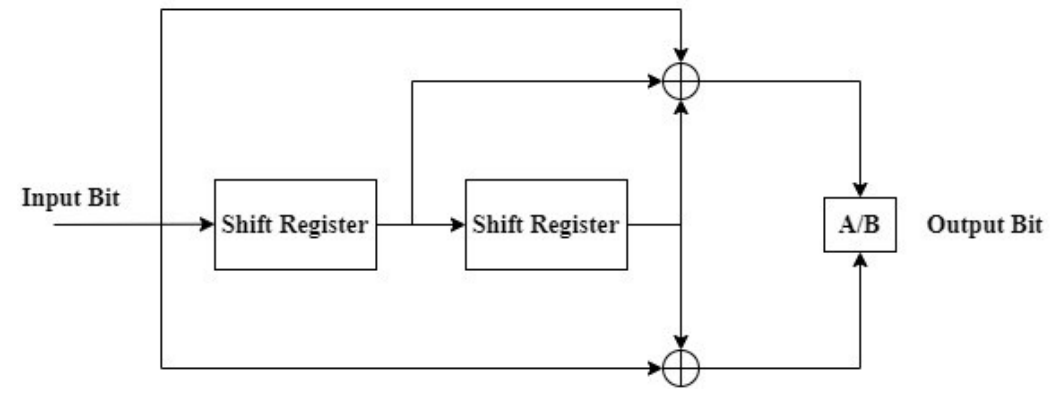

Gambar 3. Blok Diagram Encoder Kode Konvolusi

\subsection{Modulasi OQAM}

Pada modulasi OQAM terdapat 2 tahap, yaitu tahap pra pengolahan OQAM dan tahap pasca pengolahan OQAM. Pada pra pengolahan OQAM terdapat 2 tahapan, tahapan yang pertama yaitu mengubah bilangan kompleks menjadi bilangan riil, bilangan riil dan imajiner dari bilangan kompleks dipisahkan lagi untuk menjadi 2 simbol baru, simbol-simbol baru tersebut memiliki urutan yang tergantung dari nomor subchannel-nya. Proses konversi dari kompleks ke riil berbeda-beda untuk setiap subchannel-nya, tergantung dengan ururtan channel, apakan subchanne/ ganjil atau subchanne/ genap. Proses ini juga dinamakan dengan proses staggering. Tahapan kedua yaitu penggandaan seperti Gambar 4 (Hendry \& Isnawati, 2019). 


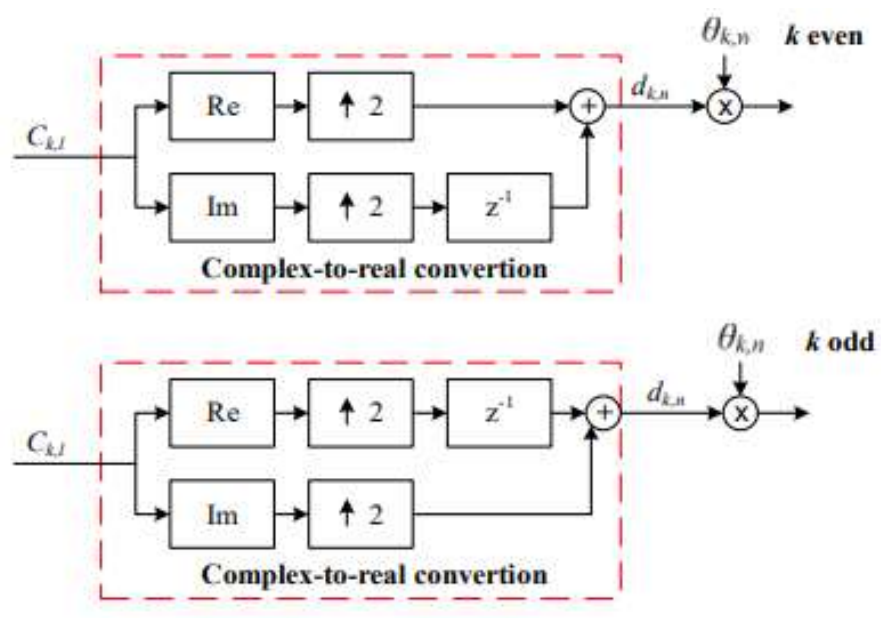

Gambar 4. Pra Pengolahan OQAM

Tahapan dari pasca pengolahan OQAM sama seperti tahapan pra pengolahan OQAM, namun 2 tahapan pada pasca pengoalahan OQAM merupakan kebalikan dari tahapan pra pengolahan OQAM. Tahapan pertama pada pasca pengolahan OQAM yaitu perkalian dengan conjugate dari $\theta_{k, n}$ untuk mendapatkan bilangan riil. Tahapan kedua yaitu mengubah bilangan riil menjadi bilangan kompleks, 2 simbol riil berturut-turut (1 simbol dikalikan dengan j) akan membentuk simbol kompleks, proses ini dinamakan juga dengan proses destraggering. Mengubah bilangan kompleks menjadi bilangan riil menurunkan laju sampel dengan faktor 2. Tahap pasca pengolahan OQAM ditunjukkan pada Gambar 5 (Hendry \& Isnawati, 2019).

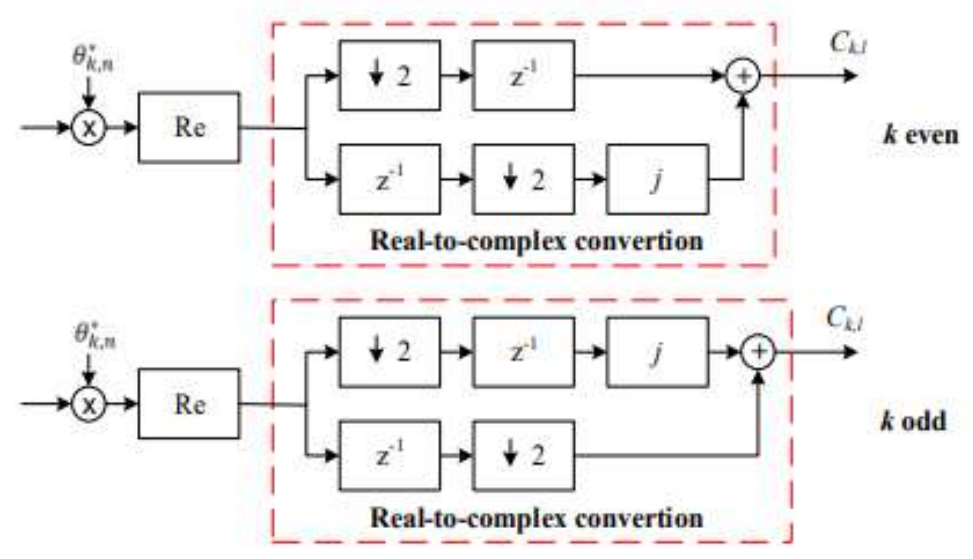

Gambar 5. Pasca Pengolahan OQAM

\subsection{Filter Bank Multicarier (FBMC)}

Sistem FBMC terdiri dari 2 proses utama, yaitu pra pemrosesan dan pasca pemrosesan. Pada pra pemrosesan terdapat proses Inverse Fast Fourier Transform (IFFT) dan proses filter. Pra pemrosesan juga dinamakan sebagai synthesis filter bank, synthesis filter bank berfungsi untuk memisahkan sinyal berdasarkan frekuensinya. Filter yang digunakan pada pra pemrosesan dapat menggunakan berbagai jenis filter (Hendry \& Isnawati, 2019).

Pasca pemrosesan terdiri dari proses filter dan proses Fast Fourier Transform (FFT), proses in juga disebut sebagai analysis filter bank. Filter yang digunakan harus sesuai dengan filter yang digunakan pada synthesis filter bank. Fungsi analysis filter bank merupakan kebalikan 
dari synthesis filter bank yaitu berfungsi untuk menggabungkan sinyal berdasarkan frekuensinya.

\subsection{Kanal AWGN}

Additive White Gaussian Noise (AWGN) merupakan noise yang terjadi dan berada pada kanal rentang spektrum frekuensi dan merupakan noise thermal yang sifatnya menjumlah atau additive. Kanal AWGN memiliki model dengan distribusi acak (gaussian) dengan mean $(m)=$ 0 standar deviasi $(\sigma)=1$, dan power spectral density $(\mathrm{pdf})=\mathrm{No} / 2(\mathrm{~W} / \mathrm{Hz})$ serta mempunyai rapat spektral daya yang tersebar merata pada lebar pita frekuensi tak hingga (noise white) (Rosita \& Ansori, 2013). Model kanal AWGN dapat dimodelkan dengan fungsi matematis pada Persamaan (1) (Ramadiansyah, 2017).

$$
r(t)=\operatorname{Si}(t)+n(t), 0<t<T
$$

Dimana $\mathrm{r}(\mathrm{t})$ merupakan sinyal $\mathrm{Si}(\mathrm{t})$ yang telah dicampur dengan noise $\mathrm{n}(\mathrm{t})$ dengan noise pada selang waktu $0<\mathrm{t}<\mathrm{T}$.

\subsection{Algortima Viterbi}

Algoritma viterbi berperan sebagai decoding dari pengkodean kanal kode konvolusi. Decoding merupakan proses mengembalikan bit informasi yang telah mengalami proses encoding menjadi bit informasi yang sesungguhnya. Algoritma viterbi menggunakan persyaratan algoritma maximum likelihood atau mencari kemungkinan bit yang paling mirip (Rosita \& Ansori, 2013). Metode yang digunakan pada penelitian ini adalah hard decision. Pada hard decision decoding bekerja dengan prinsip maximum likelihood yaitu mencari kemungkinan dari bit yang paling mirip atau nilai hamming distance yang paling kecil. Nilai tersebut merupakan nilai yang digunakan untuk menentukan jalur selanjutnya pada diagram trellis.

\subsection{Bit Error Rate (BER)}

Bit Error Rate (BER) merupakan nilai yang menunjukan jumlah terjadinya error tiap jumlah bit data yang terkirim. BER juga disebut dengan probabilitas munculnya error pada transmisi data atau error probability. Semakin kecil nilai dari BER maka semakin baik pula informasi yang didapatkan. Berikut persamaan untuk menghitung nilai BER (Adiati, dkk, 2017):

$$
\text { BER }=(\text { Jumlah bit error }) /(J u m l a h \text { bit yang dikirim })
$$

Sedangkan persamaan BER teori untuk kanal AWGN dengan modulasi 16 QAM sebagai berikut (Pallam, dkk, 2015):

$$
\text { BER Teori }=3 / 8 \operatorname{erfc}(\sqrt{(2 / 5 S N R)})-9 / 64 \operatorname{erfc}(\sqrt{ }(2 / 5 \text { SNR }))^{\wedge} 2
$$

\subsection{Signal To Noise Ratio (SNR)}

Signal to Noise Ratio (SNR) merupakan parameter yang digunakan untuk menunjukan seberapa banyak noise mengganggu sinyal yang ditransmisikan. SNR membandingkan daya sinyal yang diinginkan dengan background noise. Semakin besar nilai SNR semakin baik kualitas yang dihasilkan. Nilai SNR hanya dipengaruhi oleh nilai daya sinyal dan nilai daya noise. Berikut persamaan dari SNR (Adiati, dkk, 2017):

$$
\operatorname{SNR}(\mathrm{dB})=10 \log (\text { Daya sinyal rata }- \text { rata }) /(\text { Daya Noise })
$$




\subsection{Kapasitas Kanal}

Kapasitas kanal diartikan sebagai kemampuan suatu kanal atau media transmisi untuk menyalurkan informasi berdasarkan lebar pita dan SNR. Semakin besar kapasitas kanal dari suatu sistem maka semakin baik sistem tersebut. Shannon theory dapat digunakan untuk menghitung kapasitas kanal pada sistem Single Input Single Output (SISO), berikut persamaan untuk menghitung nilai kapasitas kanal (Isnawati, dkk, 2019):

Dimana:

$$
\mathrm{C}=\log 2(1+\mathrm{SNR}) \quad \mathrm{bps} / \mathrm{Hz}
$$

C : Kapasitas kanal.

SNR : Signal to Noise Ratio.

\section{HASIL DAN PEMBAHASAN}

\subsection{Sistem Uncoded FBMC OQAM}

Simulasi sistem uncoded FBMC OQAM dilakukan menggunakan software Matlab mengikuti pemodelan sistem uncoded FBMC OQAM pada Gambar 1. Grafik unjuk kerja sistem FBMC OQAM uncoded dapat dilihat pada Gambar 6.

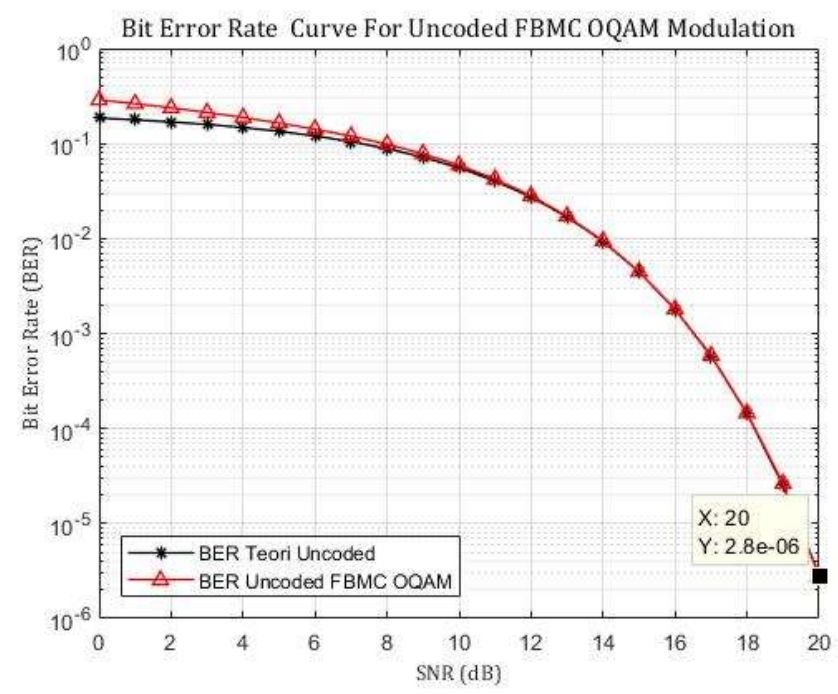

Gambar 6. Grafik Unjuk Kerja Sistem Uncoded FBMC OQAM

Pada Gambar 6 terlihat hasil simulasi menunjukkan ketika pada SNR 0 dB rata-rata nilai BER yang dihasilkan sebesar 0,2873. Sedangkan SNR $20 \mathrm{~dB}$ menghasilkan nilai BER sebesar $2,8 \times 10^{-6}$. Pada sistem uncoded FBMC OQAM untuk mencapai nilai BER $10^{-3}$ membutuhkan nilai SNR $17 \mathrm{~dB}$. Nilai BER yang dihasilkan berbanding terbalik dengan nilai SNR, semakin besar nilai SNR maka akan semakin kecil nilai BER yang dihasilkan. Hal ini dikarenakan nilai noise yang terdapat pada kanal semakin kecil apabila nilai SNR yang digunakan besar. Sedangkan jika nilai SNR yang digunakan bernilai kecil maka nilai noise yang terdapat pada kanal AWGN akan semakin besar dan akan menghasilkan BER yang besar pula.

\subsection{Sistem Coded FBMC OQAM}

Simulasi sistem FBMC OQAM dengan pengkodean kanal kode konvolusi dilakukan menggunakan software Matlab mengikuti pemodelan sistem pada Gambar 2. Grafik unjuk kerja sistem FBMC OQAM dengan kode konvolusi dapat dilihat pada Gambar 7. 


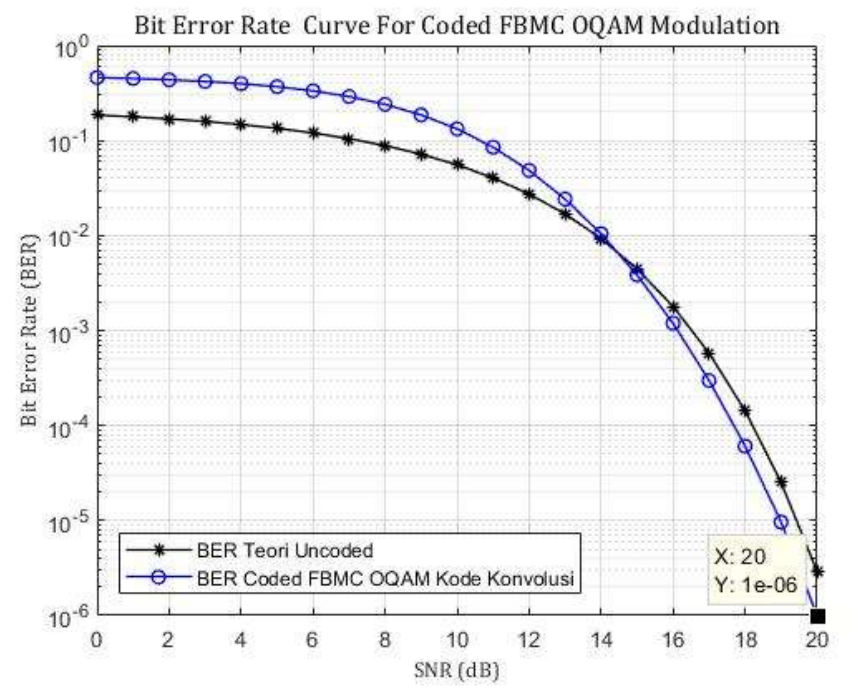

Gambar 7. Grafik Unjuk Kerja Sistem Coded FBMC OQAM

Pada Gambar 7 terlihat grafik unjuk kerja sistem FBMC OQAM dengan pengkodean kanal menggunakan kode konvolusi untuk mencapai nilai BER $10^{-3}$ membutuhkan nilai SNR sebesar $16 \mathrm{~dB}$. Nilai rata-rata BER yang didapatkan pada SNR $0 \mathrm{~dB}$ sebesar 0,4599 . Sedangkan nilai BER yang didapatkan ketika nilai SNR $20 \mathrm{~dB}$ sebesar $1,0 \times 10^{-6}$. Nilai BER yang dihasilkan pada sistem coded FBMC OQAM dengan kode konvolusi mengalami penurunan. Hal tersebut dikarenakan penggunaan pengkodean kanal kode konvolusi. Sama seperti sistem uncoded FBMC OQAM, pada sistem coded FBMC OQAM dengan kode konvolusi semakin besar nilai SNR akan semakin kecil nilai BER yang didapatkan. Hal ini dikarenakan noise yang ada pada kanal AWGN semakin kecil apabila nilai SNR yang digunakan besar.

\subsection{Perbandingan Sistem Uncoded dan Coded FBMC OQAM}

Perbandingan unjuk kerja antara sistem uncoded FBMC OQAM dan coded FBMC OQAM dengan kode konvolusi dapat ditunjukkan pada grafik perbandingan BER terhadap SNR pada Gambar 8.

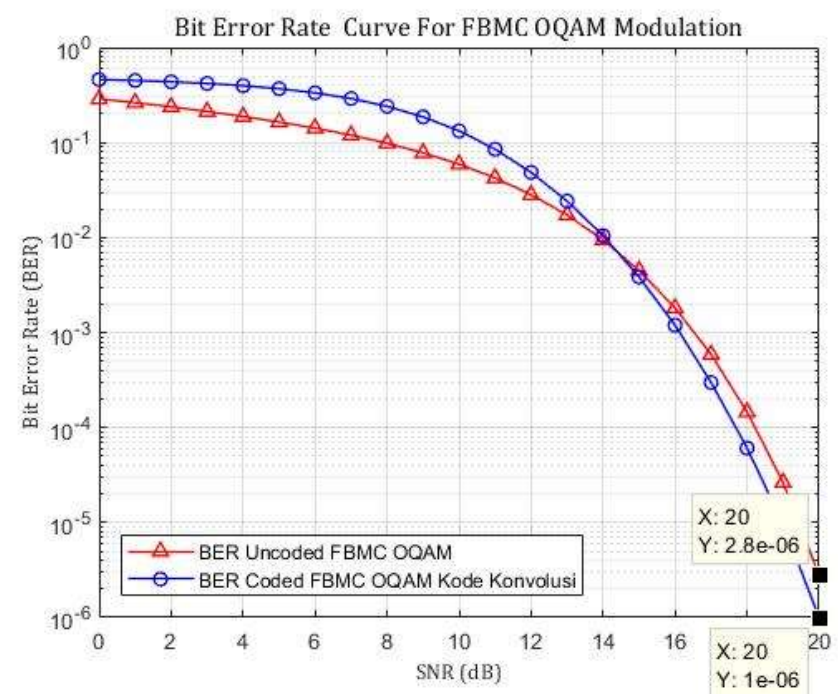

Gambar 8. Grafik Unjuk Kerja Sistem Uncoded dan Coded FBMC OQAM 
Berdasarkan grafik perbandingan nilai BER terhadap SNR pada Gambar 8, untuk mencapai nilai BER $10^{-3}$ pada sistem uncoded FBMC OQAM membutuhkan nilai SNR $17 \mathrm{~dB}$. Sedangkan pada sistem coded FBMC OQAM untuk mencapai nilai BER $10^{-3}$ membutuhkan nilai SNR 16 dB. Namun pada nilai SNR kecil pada sistem coded FBMC OQAM nilai BER lebih besar daripada sistem uncoded FBMC OQAM. Semakin besar nilai SNR, nilai BER yang dihasilkan pada sistem FBMC OQAM akan semakin kecil dan lebih kecil daripada sistem uncoded FBMC OQAM.

Pada nilai SNR $0 \mathrm{~dB}$ sampai SNR $14 \mathrm{~dB}$ nilai BER yang didapatkan pada sistem uncoded lebih kecil daripada sistem coded FBMC OQAM. Namun pada nilai SNR $15 \mathrm{~dB}$ sampai SNR $20 \mathrm{~dB}$ nilai BER yang didapatkan sistem coded FBMC OQAM dengan kode konvolusi lebih kecil daripada sistem uncoded FBMC OQAM. Dapat disimpulkan bahwa performansi dari sistem coded FBMC OQAM dengan kode konvolusi lebih baik daripada sistem uncoded FBMC OQAM pada nilai SNR tinggi. Selisih nilai BER antara sistem uncoded FBMC OQAM dan sistem coded FBMC OQAM menggunakan kode konvolusi dapat mencapai $1,8 \times 10^{-6}$ pada SNR $20 \mathrm{~dB}$.

\subsection{Pengujian Kapasitas Kanal}

Hasil pengujian kapasitas kanal dengan jenis komunikasi SISO pada kanal AWGN ditunjukkan pada Gambar 9.

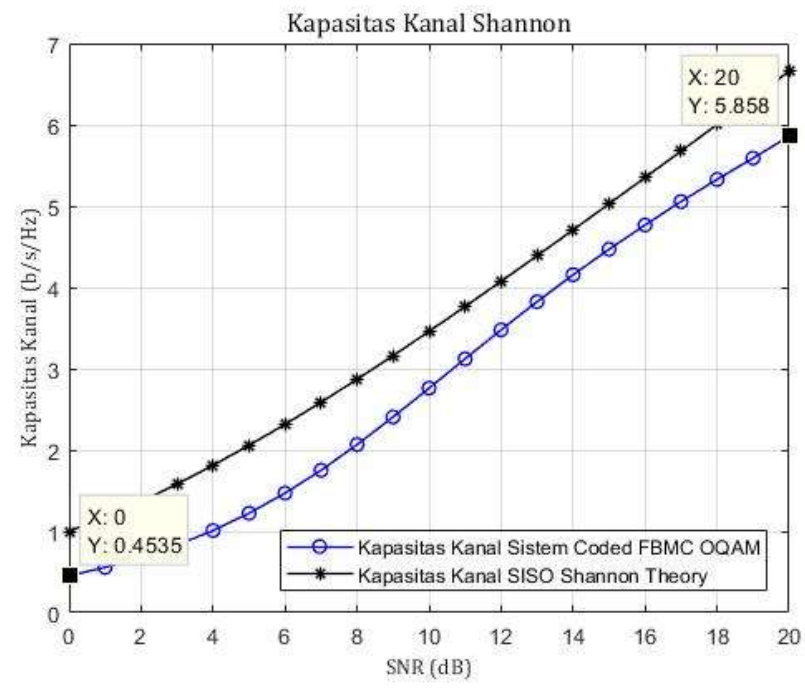

Gambar 9. Kapsitas Kanal

Berdasarkan Gambar 9, terlihat bahwa grafik kapasitas kanal dengan penerapan kode konvolusi pada sistem FBMC OQAM memiliki nilai $0,4535 \mathrm{bps} / \mathrm{Hz}$ pada SNR $0 \mathrm{~dB}$. Sedangkan pada nilai SNR $20 \mathrm{~dB}$ menghasilkan kapasitas kanal sebesar 5,858 bps/Hz. Hal tersebut menunjukkan bahwa nilai kapasitas kanal mengalami kenaikan sebesar 5,4045 bps/ $\mathrm{Hz}$ dari SNR $0 \mathrm{~dB}$ sampai SNR $20 \mathrm{~dB}$. Nilai SNR berbanding lurus dengan nilai kapasitas kanal, apabila nilai SNR yang digunakan semakin besar maka nilai kapasitas kanal yang dihasilkan juga akan semakin besar.

\section{KESIMPULAN}

Berdasarkan hasil simulasi dapat disimpulkan bahwa sistem FBMC OQAM dengan pengkodean kanal menggunakan kode konvolusi mampu menghasilkan nilai BER yang lebih baik daripada sistem FBMC OQAM tanpa kode konvolusi pada nilai SNR tinggi. Pada sistem 
uncoded FBMC OQAM untuk mencapai nilai BER $10^{-3}$ membutuhkan nilai SNR $17 \mathrm{~dB}$ sedangkan pada sistem coded FBMC OQAM dengan kode konvolusi membutuhkan SNR 16 $\mathrm{dB}$. Nilai SNR berbanding lurus dengan nilai kapasitas kanal, semakin besar nilai SNR semakin besar juga nilai kapasitas kanal yang didapatkan. Seperti pada SNR 0 dB nilai kapasitas kanal yang dihasilkan 0,4535 bps/Hz dan pada SNR $20 \mathrm{~dB}$ menghasilkan kapasitas kanal sebesar 5,858 bps/Hz.

\section{DAFTAR RUJUKAN}

Adiati, R. F., Kusumawardhani, A., \& Setijono, H. (2017). Analisis Parameter Signal to Noise Ratiodan Bit Error Ratedalam BackboneKomunikasi Fiber Optik Segmen LamonganKebalen. Jurnal Teknik ITS, 6(2).

Elvia, D., Elvia, D., Suwadi, S., \& Suryani, T. (2015). Implementasi Dan Evaluasi Kinerja Kode Konvolusi Pada Modulasi Quadrature Phase Shift Keying (QPSK) Menggunakan WARP. Jurnal Teknik ITS, 4(1), A48-A52. https://doi.org/10.12962/j23373539.v4i1.8413

Hendry, J., \& Isnawati, A. F. (2019). Analisis Perbandingan Kinerja Ekualisasi Zero Forcing dan MMSE pada FBMC-OQAM. ELKOMIKA: Jurnal Teknik Energi Elektrik, Teknik $\begin{array}{lllll}\text { Telekomunikasi, } \quad \text { \& } & \text { Teknik }\end{array}$ https://doi.org/10.26760/elkomika.v7i3.600

Isnawati, A. F., Citra, V. O., \& Hendry, J. (2019). Performance Analysis of Audio Data Transmission on FBMC-Offset QAM System. Proceedings - 2019 IEEE International Conference on Industry 4.0, Artificial Intelligence, and Communications Technology, IAICT 2019, (September), 81-86. https://doi.org/10.1109/ICIAICT.2019.8784810

Isnawati, A. F., \& Hendry, J. (2019). Implementasi Filter Pre-Emphasis untuk Transmisi

Sinyal Audio pada Sistem Komunikasi FBMC-OQAM. Jurnal Nasional Teknik Elektro Dan

Teknologi Informasi (JNTETI), 8(4), 340. https://doi.org/10.22146/jnteti.v8i4.534

Lynn, R., \& Calvinus, Y. (2017). Kajian Dan Simulasi Prinsip Kerja Coded Orthogonal Frequency Division Multiplexing Untuk Sistem Transmisi Radio Over Fiber, 19(2), 156171.

Mahyadi, A., \& Arifin. (2011). Visualisasi Kinerja Pengkodean Menggunakan Algoritma Viterbi. Politeknik Elektronika Negeri Surabaya, Jurusan Teknik Telekomunikasi, 1-5.

Mamiek, R. R., \& Moegiharto, Y. (2014). Visualisasi dan Analisa Kinerja Kode Konvolusi Pada Sistem MC-CDMA, 2, 40-50.

Pallam, S. W., Luka, M. K., \& Aminu, M. (2015). BER Evaluation of M-QAM Modulation in Wireless Transmission Over AWGN Channel, (February).

Prayoga, K. A. M. D., Wirastuti, N. M. A. E. D., \& Hartawan, I. G. A. K. D. D. (2017). Analisis 
Unjuk Kerja Convolutional Code pada Sistem MIMO MC-DSSS Melalui Kanal Rayleigh $\begin{array}{lllll}\text { Fading. Majalah IImiah Teknologi Elektro, } 66 . & \end{array}$ https://doi.org/10.24843/mite.2017.v16i02p11

Pushpa, V., Ranganathan, H., \& Palanivelan, M. (2017). BER Analysis of BPSK for Block Codes and Convolution Codes Over AWGN Channel. International Journal of Pure and Applied Mathematics, 114(11), 221-230.

Ramadiansyah, F. H. (2017). Generalized Frequency Division Multiplexing Dengan Menggunakan Offset Quadrature Amplitude.

Rosita, E. K., \& Ansori, A. (2013). Implementasi Convolutional Code dan Viterbi Decode pada DSK TMS320C6416T, 2(1).

Utomo, F., Wirastuti, N., \& Hartawan, I. (2015). Analisis Unjuk Kerja Coded Ofdm Menggunakan Kode Convolutional Pada Kanal Awgn Dan Rayleigh Fading. Jurnal IImiah SPEKTRUM, 2(2), 154-160.

Zain, A. R., Moegiharto, Y., Politeknik, M., Negeri, E., Telekomunikasi, J. T., \& Konvolusi, K. (2013). Analisa Kinerja Kode Konvolusi pada Sistem PIC ( Parallel Interference Cancellation ) MUD ( Multiuser Detection ) CDMA dengan Modulasi QAM Berbasis Perangkat Lunak, 1-7. 